\title{
The Effect of Poverty Alleviation Policy on the Regional Economic Development: Evidence from the County Level
}

\author{
Yan Yang \\ School of Economics, Jinan University, Guangzhou, China \\ Email: 1529811596@qq.com
}

How to cite this paper: Yang, Y. (2017) The Effect of Poverty Alleviation Policy on the Regional Economic Development: Evidence from the County Level. Modern Economy, 8, 1-9.

http://dx.doi.org/10.4236/me.2017.81001

Received: December 6, 2016

Accepted: January 6, 2017

Published: January 9, 2017

Copyright $\odot 2017$ by author and Scientific Research Publishing Inc. This work is licensed under the Creative Commons Attribution International License (CC BY 4.0)

http://creativecommons.org/licenses/by/4.0/

\begin{abstract}
Based on the county-level panel data from 1997 to 2010, the influence of national poverty alleviation policy on economic development in the new period was analyzed by the method of difference in difference. The results show that GDP in non-poverty area is varied from $84 \%$ to $65.7 \%$, higher than poverty area; therefore, the gap has narrowed by $18.3 \%$. Besides, the effect on regional economy has an upward trend. This study confirms the effectiveness of the national poverty alleviation program.
\end{abstract}

\section{Keywords}

Poverty Alleviation Program, Economic Development,

Difference in Difference

\section{Introduction}

Poverty has hindered economic development and people's income level in the world (Yu, 1998) [1]. Dollar \& Kraay (2002) [2] showed that economic growth was the key to reduce poverty. However, Du and Sun (2009) [3] found that 1991-1997 poor people benefited from the economy less than non-poor people, but it was opposite during 1997-2004. In general, economic growth process driven by market forces will benefit the rich rather than the poor. This is not only because the rich in the market economy mechanism have many comparative advantages, and the rich have high returns in the initial allocation. What is more, it is because the poor lack of assets and the production factor is cheap. In the primary distribution of labor, income rate is very low, so depending on the natural growth of economy profit will enlarge the gap between rich and poor (Luo, 2012) [4]. Therefore, in order to overcome the poverty, economic growth should 
be attached great importance. At the same time, we should also pay close attention to the poverty alleviation policy (Lin, 2003) [5].

Since the 1990s, the central government implemented a large targeted development-oriented poverty reduction policy. With the determination of poor counties, poverty alleviation funds were applied for water, electricity, roads and other infrastructure construction; culture, education and other public welfare services; planting, breeding and other productive projects. Among them, "Seven-Year Priority Poverty Alleviation Program" was announced in 1994; this plan identified 592 poor counties in order to solve the problem of food and clothing of 80 million poor people. In the new century, the state again issued the "National Program for Rural Poverty Alleviation (2001-2010)" which adjusted some poor counties and still determined 592 countries in order to further improve the economic and social situation in the poor areas. Taking it as a symbol, China's poverty-relief work has entered a new period. From 2001 to 2010, the special funds for poverty alleviation reached 182.386 billion, maintaining the growth rate of 11.7 percent a year. So it's worthwhile to probe the effectiveness of this big development-oriented poverty reduction policy.

This paper will use the mainstream econometric analysis method-difference in difference, by comparing the differences between poverty counties and nonpoverty counties before and after the intervention. This poverty reduction effect of Poverty Alleviation Policies is discussed. The remainder of this article is arranged as follows: the second part introduces the relevant literature; the third part sets models and data; the fourth part analyzes regression results and the fifth part makes a summary.

\section{Literature Review}

There have been some papers evaluating its effect on the one hand, according to the source of poverty-relief funds to analyze this impact. Rozelle, et al. (1998) compared the direction of poverty alleviation funds; found that financial poverty alleviation which investment in agricultural production promoted economic growth in poor areas [6]. Cai (2000) based on the poverty alleviation funds from 1900 to 1997, found that the poverty alleviation funds were tilted to specific industries, and did not promote economic growth in poor areas as expected [7]. Liu (2001) started from the national poverty alleviation funds structure and direction; found that the effect of work relief and credit funds are better than financial funds [8]. Zhu (2004) found that investment performance of work relief is best, and financial funds have significant effects on per capita net income of farmers [9]. Jiang (2008) used the data from 592 poverty counties funds, found that funds for agriculture can reduce poverty obviously by fixed effects model [10]. Shuai (2008) used data from 1999 to 2005 in the 592 counties, analyzed the relationship between Anti-poverty funds and, indicated that funds have significant influence on each output [11]. Qiao (2009) found that the development of financial poverty alleviation funds for poverty reduction effect is greater than the effect of economic development on poverty reduction [12]. In addition, Mao, et 
al. (2012) based on the "Seven-Year Priority Poverty Alleviation Program", pointed out that policy leads the local government to put more fiscal funds to productive projects [13]. Zhang (2013) uses propensity score matching method to discuss the influence of poverty alleviation policy on Farmers' income, and thought that poverty alleviation policy has intervened on Farmers' income in poor counties [14]. Meng (2013) also based on the "Seven-Year Priority Poverty Alleviation Program", found that policy improve the per capita income of farmers in the short-term [15].

As we can see, scholars have used different methods to analyze the policy effect of poverty alleviation which has important reference value to this paper. But there are some limitations, most scholars focus on "Seven-Year Priority Poverty Alleviation Program", few scholars have discussed the third round (2001-2010) policy, this article will update data to 2010. Researching new period policy can conform to reality needs. What's more, previous studies play more attention to per capita net income of farmers, few studies on the impact of economic development in poor areas. Hence, this paper will analyze the impact of poverty alleviation policy on the economy development by the method of difference in difference.

\section{Model Design and Data}

\subsection{Model}

Using comparative method to explore the effects of poverty reduction policy, a general method on the longitudinal comparison can be used, comparing the difference of poor counties' economic development level before and after the policy. But it has the influence of the time trend; maybe not have the policy, poverty county's economic development will also changes over time, the longitudinal comparison is difficult to accurately judge. Of course we can use a horizontal comparison, comparing the difference between poor counties' and non-poor counties' economic development level after this policy. But this ignores the individual differences. Horizontal comparison is also difficult to examine the effects of poverty alleviation policy accurately. Hence, this article will use the double difference method (difference in difference), considering the individual difference and time difference, to analyze the effects of policy exactly.

We construct a dummy variable $N P_{i}$. If $i$ county is poor county (treatment group), the value is 1 , opposite is 0 (control group). Construct a time dummy variable $d_{t}$ again, it is assigned 1 after the implementation of the policy, before is 0 . So for poor counties, the effects of policy can be expressed as:

$$
\begin{aligned}
\delta & =E\left(Y_{i t}^{1} \mid N P_{i}=1, d_{t}=1\right)-E\left(Y_{i t}^{0} \mid N P_{i}=1, d_{t}=1\right) \\
& =E\left(\Delta Y_{i}^{1} \mid N P_{i}=1\right)-E\left(\Delta Y_{i}^{0} \mid N P_{i}=1\right) .
\end{aligned}
$$

$E$ is the mathematical expectation in the equation, $Y_{i t}^{1}$ is the observations if $i$ county participate policy at $t$ time. $Y_{i t}^{0}$ represents not participate policy. $\Delta Y_{i}^{1}$ shows the difference before and after the policy implementation if $i$ poor county 
participate policy, $\Delta Y_{i}^{0}$ shows the difference before and after the policy if $i$ poor county doesn't participate policy. It is clear that the latter could not be observed, therefore, we can use the non-poor county's difference before and after the policy to replace it. That is $E\left(\Delta Y_{i t}^{0} \mid N P_{i}=1\right)=E\left(\Delta Y_{i t}^{0} \mid N P_{i}=0\right)$, so, Equation (1) is transformed into:

$$
\delta=E\left(\Delta Y_{i}^{1} \mid N P_{i}=1\right)-E\left(\Delta Y_{i}^{0} \mid N P_{i}=0\right) .
$$

Theoretical model should be designed as follow:

$$
Y_{i t}=\alpha+\gamma N P_{i}+\lambda d_{t}+\delta N P_{i} d_{t}+\varepsilon_{i t} .
$$

In the Model (3):

$$
\begin{gathered}
E\left(\Delta Y_{i}^{1} \mid N P_{i}=1\right)=(\alpha+\gamma+\lambda+\delta)-(\alpha+\gamma)=\lambda+\delta . \\
E\left(\Delta Y_{i}^{0} \mid N P_{i}=0\right)=(\alpha+\lambda)-\alpha=\lambda . \\
E\left(\Delta Y_{i}^{1} \mid N P_{i}=1\right)-E\left(\Delta Y_{i}^{0} \mid N P_{i}=0\right)=(\lambda+\delta)-\lambda=\delta .
\end{gathered}
$$

As we can see, Equation (6) and (2) is consistent. Accordingly, in this Model (3) based on "difference in difference", the estimated coefficients of interaction $\delta$ measure the effects of poverty reduction policy.

Figure 1 shows the economic growth of two groups over the years. Before the year of 2001, poor counties are lower than the non-poor counties, the difference of economic growth rate between the two groups remained at almost $2.5 \%$. But in the policy year (2001), poor counties faster, gap narrow $1.5 \%$, almost close to the non-poor counties in year 2002, poor counties even exceed them. After 2005 poor counties economic growth is relatively slow, but the gap is diminishing. It is clear that two groups showed obvious difference before and after the implementation of policy.

Two groups remained the same change trend before policy, which is consistent with hypothesis (2). So we can set the model as:

$$
Y_{i t}=\alpha+\gamma N P_{i}+\delta N P_{i} d_{t}+\theta X_{i t}+\lambda_{t}+\varepsilon_{i t} .
$$

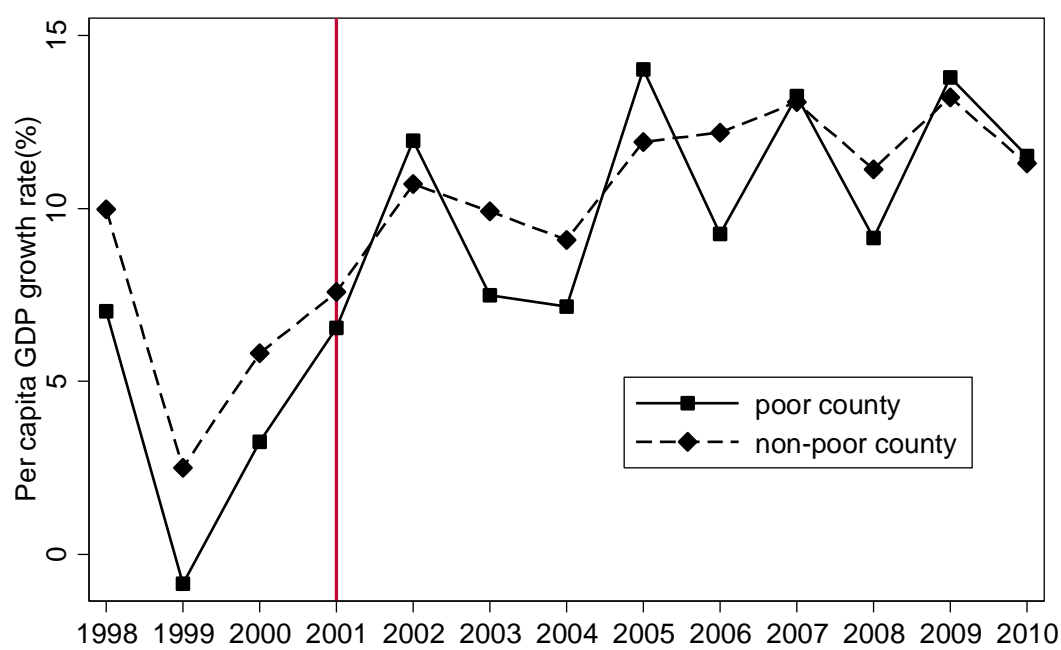

Figure 1. Per capita GDP growth rate in poor counties and non-poor counties. Note: data integration according to "China County Statistical Yearbook" and "National City and County Financial Statistics". 
$Y_{i t}$ is per capita GDP. $\alpha$ indicates Intercept, $N P_{i}$ is poor county dummy, $d_{t}$ is time dummy. $X_{i t}$ indicates the other control variables, including three groups: the first group is the geographical control variable mountain, minority county and the revolutionary areas; the second is administrative region area, rural population rate; the third group is the initial level of per capita GDP. $\lambda_{t}$ istime fixed effect. $\varepsilon_{i t}$ is residual. In order to avoid heteroscedasticity and serial correlation of residual, we will polymerize residual to the county level.

\subsection{Data Selection and Processing}

In this paper, data are derived from "China County Statistical Yearbook", "National City and County Financial Statistics" and government official document (List of 592 poor counties), covers the period from 1997 to 2010. Considering the comparability is very poor between city districts and counties, all the observations are eliminated municipal district. In addition, considering that there are some outliers in the panel data, gross domestic product has been revised. Specifically, use program to identify outliers, and adjust it by the method of interpolation. At the same time, this paper also uses the "shrinking tail method", only to retain the first percentile to ninety-ninth percentile of the data, to reduce the impact of outliers [16]. According to this, the data of this paper has higher accuracy and representation.

\section{Empirical Analysis}

\subsection{Impact of Poverty Alleviation Policy on Economic Development}

First of all, based on the county-level panel data from 1997 to 2010, we analyze the influence of poverty alleviation policy on economic development in the new period by the Model (7), because of some new poor counties are also benefited in the previous policy, therefore, the impact of "Seven-year priority poverty alleviation program" has been controlled. $\delta$ in Model (7) measures the influence of the policy in the new period.

Regression results in Table 1, as we can see, whether or not join control variable, regression results are significantly positive. Specifically, in the first column, other control variables not be added, poverty alleviation policy in the new period significantly improved the poor region's economic development level, GDP in non-poor counties varied from $84 \%$ to $65.7 \%$, higher than poor counties, therefore the gap has narrowed by $18.3 \%$.

\subsection{Dynamic Robustness Test}

Next, in order to explore the time effect of poverty reduction policy, we focus on dynamic change trend of the effect of policy, to examine robustness of the overall effect.

First, we construct 10 dummy variables of year, if the year 200i after policy, value is 1 , otherwise 0 . Hence, interactive item in Model (7) is decomposed into 10 years after the reform. The model is designed as follow: 


$$
\begin{aligned}
Y_{i t}= & \alpha+r N P_{i}+\delta_{1} N P_{i} d_{t} \text { year }^{2001}+\delta_{2} N P_{i} d_{t} \text { year }^{2002} \\
& +\cdots+\delta_{10} N P_{i} d_{t} \text { year }^{2010}+\theta X_{i t}+\lambda_{t}+\varepsilon_{i t} .
\end{aligned}
$$

Figure 2 shows the dynamic change trend and significant degree of effect variable coefficients ( $\delta_{1}$ to $\delta_{10}$ ) which do not add control variables. As we can see, the estimated coefficients of each year after the implementation of policy are significantly positive, this shows that policy continues to be effective, improve the level of economic development in poor areas every year. On the other hand, we can see that the estimated coefficients have been increasing, which may imply that the resources may be more involved in long-term development projects, rather than short-term item which pursuit an immediate result. This is consistent with regulation issued by National Poverty Alleviation Office.

\subsection{Test by Adjusting Control Group}

Next, we test the robustness of the empirical results by adjusting the control group. In the year of 2001, nation determined 592 national poor counties, at the same time also identified 421 provincial poor counties. We take 421 provincial

\begin{tabular}{|c|c|c|c|c|}
\hline \multirow{2}{*}{$\begin{array}{c}\text { Independent } \\
\text { variable }\end{array}$} & \multicolumn{4}{|c|}{ Per capita GDP (log) } \\
\hline & (1) & (2) & (3) & (4) \\
\hline \multirow[t]{2}{*}{$N P_{i} d_{t}$} & $0.183^{* * *}$ & $0.172^{* * *}$ & $0.226^{* * *}$ & $0.545^{* * *}$ \\
\hline & $(0.039)$ & $(0.039)$ & $(0.043)$ & $(0.103)$ \\
\hline \multirow[t]{2}{*}{$\begin{array}{l}\text { dummy of poor } \\
\text { county }\end{array}$} & $-0.840^{* * *}$ & $-0.784^{* * *}$ & $-0.846^{* * *}$ & $-0.892^{* * *}$ \\
\hline & $(0.054)$ & $(0.059)$ & $(0.068)$ & $(0.064)$ \\
\hline \multirow[t]{2}{*}{ mountain county } & & $-0.189^{* * *}$ & $-0.190^{* * *}$ & $-0.057^{* * *}$ \\
\hline & & $(0.064)$ & $(0.066)$ & $(0.020)$ \\
\hline \multirow[t]{2}{*}{ minority county } & & -0.013 & -0.020 & 0.008 \\
\hline & & $(0.057)$ & $(0.061)$ & $(0.023)$ \\
\hline \multirow[t]{2}{*}{ revolutionary base } & & $0.157^{* * *}$ & $0.178^{* * *}$ & $0.051^{* * *}$ \\
\hline & & $(0.054)$ & $(0.054)$ & $(0.018)$ \\
\hline \multirow[t]{2}{*}{ administrative area } & & & $0.035^{* *}$ & $0.023^{* *}$ \\
\hline & & & $(0.016)$ & $(0.010)$ \\
\hline \multirow[t]{2}{*}{ rural population rate } & & & 0.001 & 0.000 \\
\hline & & & $(0.001)$ & $(0.000)$ \\
\hline \multirow[t]{2}{*}{ initial economic level } & & & & $0.887^{* * *}$ \\
\hline & & & & $(0.049)$ \\
\hline fixed effects of year & yes & yes & yes & yes \\
\hline samples & 27702 & 27702 & 23322 & 23293 \\
\hline$R^{2}$ & 0.225 & 0.236 & 0.242 & 0.754 \\
\hline
\end{tabular}

Table 1. Poverty alleviation policy and economic development.

Note: Robust standard errors in parentheses, ${ }^{*} \mathrm{p}<0.10,{ }^{* *} \mathrm{p}<0.05,{ }^{* *} \mathrm{p}<0.01$. 


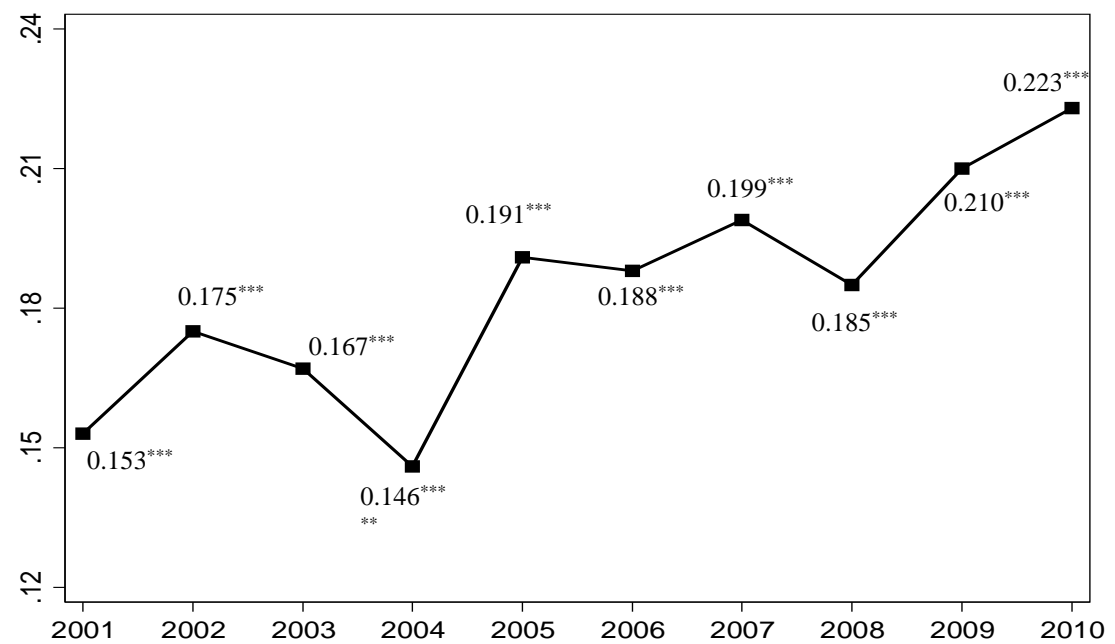

Figure 2. Dynamic change trend of policy effect. Note: robust standard errors in parentheses, ${ }^{*} \mathrm{p}<0.10,{ }^{* *} \mathrm{p}<0.05,{ }^{* * *} \mathrm{p}<0.01$.

Table 2. Robustness test results.

\begin{tabular}{|c|c|c|c|c|}
\hline \multirow{2}{*}{$\begin{array}{l}\text { Independent } \\
\text { variable }\end{array}$} & \multicolumn{4}{|c|}{ Per capita GDP (log) } \\
\hline & (1) & (2) & (3) & $(4)$ \\
\hline \multirow[t]{2}{*}{$N P_{i} d_{t}$} & $0.410^{* * *}$ & $0.482^{* * *}$ & $0.405^{* * *}$ & $0.477^{* * *}$ \\
\hline & $(0.117)$ & $(0.123)$ & $(0.117)$ & $(0.123)$ \\
\hline \multirow[t]{2}{*}{ dummy of poor county } & $-0.547^{* * *}$ & $-0.628^{* * *}$ & $-0.537^{* * *}$ & $-0.617^{* * *}$ \\
\hline & $(0.063)$ & $(0.069)$ & $(0.064)$ & $(0.071)$ \\
\hline \multirow[t]{2}{*}{ initial economic level } & $0.916^{* * *}$ & $0.914^{* * *}$ & $0.910^{* * *}$ & $0.909^{* * *}$ \\
\hline & $(0.058)$ & $(0.059)$ & $(0.058)$ & $(0.059)$ \\
\hline \multirow[t]{2}{*}{ administrative area } & & $0.052^{* * *}$ & & $0.045^{* *}$ \\
\hline & & $(0.017)$ & & $(0.019)$ \\
\hline \multirow[t]{2}{*}{ rural population rate } & & $0.001^{*}$ & & $0.001^{*}$ \\
\hline & & $(0.001)$ & & $(0.001)$ \\
\hline \multirow[t]{2}{*}{ mountain county } & & & $-0.079^{* *}$ & $-0.067^{* *}$ \\
\hline & & & $(0.037)$ & $(0.031)$ \\
\hline \multirow[t]{2}{*}{ minority county } & & & $0.064^{* *}$ & 0.039 \\
\hline & & & $(0.028)$ & $(0.026)$ \\
\hline \multirow[t]{2}{*}{ revolutionary base } & & & $0.061^{*}$ & $0.059^{* *}$ \\
\hline & & & $(0.033)$ & $(0.025)$ \\
\hline fixed effects of year & yes & yes & yes & yes \\
\hline samples & 13388 & 11316 & 13388 & 11316 \\
\hline$R^{2}$ & 0.674 & 0.754 & 0.676 & 0.755 \\
\hline
\end{tabular}

Note: Robust standard errors in parentheses, ${ }^{*} \mathrm{p}<0.10,{ }^{* *} \mathrm{p}<0.05,{ }^{* * *} \mathrm{p}<0.01$. 
poor counties as control group. Doing this, on the one hand, we do further observation by reducing the amount of samples. On the other hand, provincial poor counties have not accepted the state support, but accepted the support of the province. Therefore, the two groups are more comparable. In fact, this is also consistent with the assumptions mentioned in the theoretical framework.

First of all, we still control the impact of "Seven-Year Priority Poverty Alleviation Program", Secondly, taking into account the difference between the two groups in the level of economic development is relatively small, and it is difficult to accurately identify the effect of Policy in the new era. So, we control the initial economic development level in all regressions, in order to control the interference of other factors at large. The results are shown in Table 2, the coefficients of policy effect we have investigated are all significantly positive. It shows that national poor counties grow faster than provincial poor counties under the national poverty alleviation policy. Take the first column as an example, the per capita GDP of the national poor counties increased by 0.410 relative to the provincial poor counties.

\section{Conclusions}

National large-scale poverty alleviation policy has this mechanism "poverty alleviation counties-get poverty alleviation funds-improve production conditions-promote regional economic development". In this paper, we use the county-level panel data from 1997 to 2010 to explore the causal relationship between the policy and economic development in the new period, and further analyze the dynamic effect of the policy.

The results show that the national poverty alleviation policy promotes the economic development of the poor counties in the new period, and raises the level of GDP. Before the implementation of policy, the non-poor counties' GDP is 84 percentage points, higher than the poor counties and after this policy, it is only 65.7 percentage points higher; the gap has narrowed by 18.3 percentage points. In addition, over time, this effect has an upward trend.

For this suggestion, national large-scale poverty alleviation policy, as a whole, is effective. The state should intensify our efforts to fight against poverty. It is

better to use these resources more effective rather than doubt the effectiveness of the policy.

\section{References}

[1] Yu, F.D. (1998) World Poverty Status, Poverty Reduction Measures. World Economy, 2, 9-13.

[2] Dollar, D. and Kraay, A. (2002) Growth Is Good for the Poor. Journal of Economic Growth, 7, 195-225. https://doi.org/10.1023/A:1020139631000

[3] Du, F.L. and Sun, J.F. (2009) Economic Growth, Income Distribution and Poverty Reduction Effect-Based on the 1991-2004 Panel Data. Economic Science, 3, 15-26.

[4] Luo, C.L. (2012) Economic Growth, Income Gap and Rural Poverty. Economic Research Journal, 2, 15-27.

[5] Lin, B.Q. (2003) China's Economic Growth, Poverty Reduction and Policy Choice. 
Economic Research, 12, 15-25.

[6] Rozelle, S., Park, A., Benzigerand, V. and Ren, C. (1998) Targeted Poverty Investments and Economic Growth in China. World Development, 26, 2137-2151. https://doi.org/10.1016/S0305-750X(98)00104-1

[7] Cai, F. and Du, Y. (2000) Investment Guidance of China's Western Development Strategy: Implications for the Use of National Poverty Alleviation Funds. World Economy, 11, 14-19.

[8] Liu, D.M. (2001) Empirical Research on the Effect of Chinese Government Development Poverty Alleviation Fund. Management World, 6, 123-131.

[9] Zhu, Q.Y. (2004) Multiple Regression Analysis of Government Poverty Alleviation Fund. Journal of Central University of Finance and Economics, 7, 11-15.

[10] Jiang, A.H. (2008) An Empirical Analysis on the Effect of the Government Development Funds for Poverty Alleviation in China. Journal of Central University of Finance and Economics, 2, 13-18.

[11] Shuai, C.M. and Liang, S.K. (2008) An Empirical Analysis on the Input Performance Poverty Alleviation Counties. Journal of Economic Problem, 6, 84-86.

[12] Qiao, Z.Q. (2009) Poverty Alleviation Policy, the Impact of Economic Growth on Poverty Alleviation. Social Sciences in Yunnan, 2, 106-108.

[13] Mao, J. (2012) Poverty Reduction Policies and Local Government Public Spending: An Empirical Study Based on the 8-7 Plan. Quarterly Journal of Economics, 4, $1365-1388$.

[14] Zhang, B.B. (2013) Policy Poverty Alleviation in the New Period: Target Selection and Farmers' Income. Economics Quarterly, 3, 959-982.

[15] Meng, L.S. (2013) Evaluating China's Poverty Alleviation Program: A Regression Discontinuity Approach. Journal of Public Economics, 101, 1-11. https://doi.org/10.1016/j.jpubeco.2013.02.004

[16] Liu, C., Qiao, K.Y. and Zhou, L.A. (2014) The Different Effects of Administrative Decentralization and Fiscal Decentralization: Empirical Evidence from China's Counties. World Economy, 10, 125-146.

Submit or recommend next manuscript to SCIRP and we will provide best service for you:

Accepting pre-submission inquiries through Email, Facebook, LinkedIn, Twitter, etc. A wide selection of journals (inclusive of 9 subjects, more than 200 journals)

Providing 24-hour high-quality service

User-friendly online submission system

Fair and swift peer-review system

Efficient typesetting and proofreading procedure

Display of the result of downloads and visits, as well as the number of cited articles

Maximum dissemination of your research work

Submit your manuscript at: http://papersubmission.scirp.org/

Or contact me@scirp.org 